\title{
ENTREPRENEURIAL-BASED ENGLISH LEARNING (MISS MAYA) TO BUILD ENTREPRENEURIAL LEADERSHIP FOR COLLEGE STUDENTS
}

\author{
Eko Heriyanto ${ }^{1}$, Amin Khudlori ${ }^{2}$ \\ ${ }^{1}$ English Literature, Faculty of Language and Culture, Universitas AKI, Semarang, Indonesia \\ eko.heriyanto@unaki.ac.id \\ ${ }^{2}$ English Literature, Faculty of Language and Culture, Universitas AKI, Semarang, Indonesia \\ amin.khudlori@unaki.ac.id
}

\begin{abstract}
The industrial revolution is a fusion of automation technology with cyber. The current trend in the industrial world is starting to touch the virtual world with several systems such as cyber physical systems, internet of things (IoT), cloud computing, and cognitive computing. Revolution 4.0 implements intelligent technology connected to various life lines, including students' needs. They must be active to form their entrepreneurial leadership to face these challenges. Absolutely, this must be supported by encouragement, collaboration and integration of learning in the field of entrepreneurship. The purposes of this research are to describe the steps of implementing the Miss Maya, to find and describe the advantages of Miss Maya in building a concrete entrepreneurial leadership, and to determine the effectiveness of Miss Maya in English learning. The method used is mix method; qualitative and quantitative research design. Primary data include references/ literature/ journals/ books related to the discussion. Secondary data include documentation and field data of the implementation obtained through observation and interviews. The results of this research are the implementation of Miss Maya can be done through the preparation, implementation and assessment. Through t-test analysis which showed that sig. (2-tailed) of all $=0.000$ and the probability less than 0.05, Miss Maya is an effective strategy to be used in English learning. Miss Maya is a futuristic imaginative integrative English learning method with six main elements of doing business which is expected to be able to foster the students' entrepreneurial leadership to face the industrial revolution 4.0.
\end{abstract}

Keywords: industrial revolution 4.0; entrepreneur; English learning.

The direction of industrial policy, like it or not, has consciously undergone significant changes towards the 4.0 industrial revolution. It was Klaus Martin Schwab (Schwab, 2016), a well-known professor and economist from Germany, who first introduced the concept of the industrial revolution 4.0 through his book "The Fourth Industrial Revolution" in 2017. The industrial revolution was an amalgamation of automation technology with cyber technology. The trend of the industrial world is starting to touch the virtual world with several systems. Among them are physical 
systems cyber, internet of things (IoT), cloud computing, and cognitive computing. New technologies and approaches that combine the physical, digital, and biological worlds in a fundamental way will change humanity $<$ | 38 (Tjandrawinata, 2016). In short, revolution 4.0 implements intelligent technology that can be connected to various lines / areas of human life, including students.

In addition, to have an impact on environmental problems, the industrial revolution will also leave problems related to the loss of social and humanities values (Prasetyo \& Trisyanti, 2018). Students, who are referred to the agents of change, must be able to prepare themselves to face the industrial revolution 4.0, including preparing to achieve financial health independently through entrepreneurship. Absolutely, to form an intuitive spirit of students' entrepreneurial leadership, it needs encouragement, collaboration and integration of learning in the field of entrepreneurship. Encouragement may come from the entire academic community both in the academic and non-academic fields. In addition, collaboration and integration of learning in some courses integrated with business and technology are necessary to fight and overcome educated unemployment.

In the latest 2018, Central Statistics Agency (BPS) data showed that nearly $8 \%$ of more than 7 million undergraduates are unemployed. This figure increased $1.13 \%$ from 2017. However, the data from the Ministry of Research, Technology and Higher Education also showed that undergraduate unemployment reached $8.8 \%$ in 2017. The number reached more than 630.000 people. This figure, of course, still needs to be reduced by implementing the acceleration of job availability. Getting job opportunities with the emergence of new jobs or the development of existing jobs is what young people today want. Obviously, they need guidance and direction from some entrepreneurs who have had much experience in the business world.

Indonesia is considered to have great potential in economic development, especially in the field of digital progress. This is caused by the level of internet usage in this country that is increasing every year. In addition, Indonesia is one country that realizes the strategic role of language. It is inevitable that the government has tried in various ways to improve the quality of education from elementary to tertiary level throughout the country. One that has improved its achievement is the use of international language that is English. Of course, when studying English, it is very important to learn the skills and components of English itself to support students' hard and soft skill.

From the description above, the researcher designed an alternative learning strategy that is applicable to entrepreneurialbased English learning, namely MISS MAYA (My Business My Adventure); a form of integration of language education with business (entrepreneurship). This method is chosen based on the assumption that teaching English must pay attention to the age and characteristics of students as well as the challenges of the recent and the future time. Miss Maya provides an overview of the preparation for doing business and entrepreneurship in English learning. In addition, Miss Maya is expected to be able to cultivate the entrepreneurial leadership of students in the future to face and participate in welcoming the industrial era 4.0.

The purpose of this study is to describe the steps to implement the Miss Maya, to find and describe the advantages of Miss Maya in building entrepreneurial leadership, and how effective this strategy in learning 
English. Theoretically, this research can be useful to enrich references about models or methods or strategies for teaching and learning English for students, and to provide alternative data for further study. Practically, it is useful in the formation and development of entrepreneurial leadership. In addition, it is also a breakthrough in the spirit of competition towards the industrial era 4.0 with the birth of business/ entrepreneurial /ideas, marketplace both on the scale of MSMEs and unicorns.

\section{THEORITICAL REVIEW}

Miss Maya is an acronym of My Business My Adventure. Miss Maya is an alternative learning strategy that is applicable to entrepreneurial-based English learning. In other word, Miss Maya is a form of integrated learning method between language education and business (entrepreneurship). This method was created based on the assumption that teaching English must pay attention to the age and characteristics of students as well as the challenges of the recent and the future time (specific material). In second language learning, especially English, there is English learning for specific purposes, one of which is English for business. By knowing the specific reasons, the learning objectives will be more focused because they adjust to someone's needs (Chairiyani, 2013). Thus, learning related to specific job-related functions will make it more relevant in the context of the discussion. Learning English should be taught by integrating it with students' learning interests (Leonardi, 2009).

First Insights into Business as Sue Robbins's work is inspiring the emergence of the idea of Miss Maya. Miss Maya provides an overview of the preparation for doing business and entrepreneurship in English learning. In addition, Miss Maya is expected to be able to cultivate the entrepreneurial spirit of students in the future to face and participate in welcoming the industrial era 4.0. They are expected to be able to engage in various business fields such as techno-preneurship, creative-preneurship, and others.

Miss Maya belongs to English learning for adults. This means that the learning focuses on participating, sharing, and working together as a team in completing tasks/ jobs or what so-called cooperative learning. The students freely explore their abilities and imagination in forming, managing and running an entrepreneurship (Cole \& Smith, 1993).

Entrepreneurship is an activity that requires courage to take risks and see business opportunities. However, there must also be caution in taking attitudes, steps and decisions (Suprapto, 2018). If someone takes the wrong steps, the business managed will be down (failed). Moreover, to start a business requires a lot of capital as a vital factor to start a business. Meanwhile, leadership is a set of characteristics that make someone a good leader, or a set of traits that give birth to a great leader. A person who has good leadership characteristics will be a reliable leader in managing and developing the tasks he/she is assigned to.

From the two definitions above, entrepreneurial leadership is a leadership character needed in entrepreneurship in order to become a reliable entrepreneur who is able to manage and develop the business. In carrying out various tasks, entrepreneurs must be able to combine various kinds of reducing factors such as labor, natural resources, materials and other equipment needed. An entrepreneur must also be able to produce a higher value or what so-called 
creative destruction which will increase creativity skills.

Entrepreneurship has many benefits. One of them is creating new jobs for others. In addition, the government currently gives a $\ll$ | 40 lot of support for anyone who dares to be an entrepreneur because this strategy indirectly supports the country's economy and finance as well as be able to reduce the unemployment rate significantly. Entrepreneurship is seen as a tool to save the world economy in the future. Thus, entrepreneurship is very important to teach the skills to think and behave like entrepreneurs to the younger generation of Indonesia (Özdemir, 2015).

Friedrich Engels and Louis-Auguste Blanqui were entrepreneurs who introduced and popularized the term "Industrial Revolution" in the middle of $19^{\text {th }}$ century. This industrial revolution is currently undergoing the changing phases from time to time. The last decade has entered the fourth phase, namely the industrial revolution 4.0. These changes made differences theoretically as well as being applicable in terms of their usage. There are four phases in the development of the industrial revolution. The first phase (1.0) takes the form of the invention of a machine which focuses on the mechanization of production. The second phase (2.0) has moved to a mass production stage that is integrated with quality control and standardization. The third phase (3.0) enters the mass uniformity stage which is based on computerized integration. The fourth phase (4.0) has presented the digitization and automation of the combination of the internet and manufacturing (Suwardana, 2018).

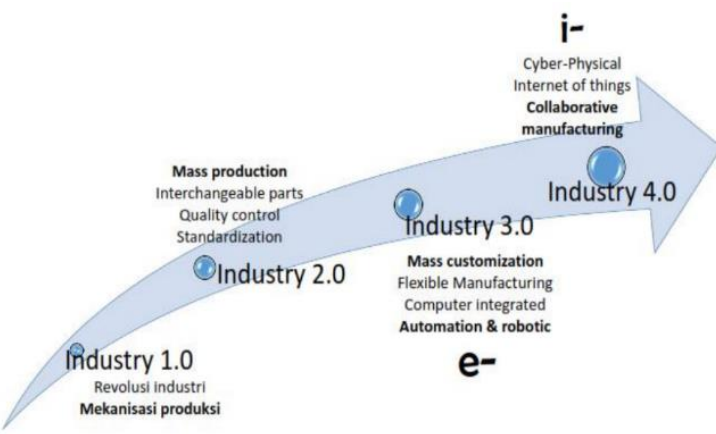

Figure 1: The Phases of Industrial Revolution

It was Klaus Martin Schwab, a wellknown professor and economist from Germany, who first introduced the concept of the industrial revolution 4.0 through his book "The Fourth Industrial Revolution" in 2017. The industrial revolution was a combination of automation technology with cyber technology. The trend of the industrial world is starting to touch the virtual world with several systems. Among them are cyber physical systems, internet of things (IoT), cloud computing, and cognitive computing. Revolution 4.0 implements intelligent technology that can be connected to various lines of life, including students' needs.

It can be inferred that in the context of the industrial revolution, the process actually happens is the social and cultural changes that take place quickly and in the basic concerns of basic needs and desire of the community. The Industrial Revolution has changed the way humans work from manual use to automation or digitization. Innovation is the key to the existence of change itself.

\section{METHOD}

The research used mixed methods; descriptive qualitative based on literature review and quantitative research methods. This qualitative method aims at describing phenomena or relationships between 
phenomena being studied in a systematic, factual and accurate manner (Sugiyarto \& Kusmayadi, 2009). Furthermore, Sudaryanto (1986)explains that the descriptive method in language research means studying the phenomenon of language empirically and only based on the facts of the speaker so that the results of this method related to be portraits/ conditions/ exposure according to what is in the field. Primary data include references/ literature/ journals/ books related to the discussion. Secondary data include documentation and field data of the implementation obtained through observation and interviews.

Quantitatively, it used one group pretest-posttest design. It mean that there is only one group was given learning using Miss Maya. It is also called pre-experimental research design. Mohamad (2003) defined that experimental research is observation of artificial condition that is made and managed by the researcher. The goal is to investigate whether there is a causal effect or not and measure the correlation the causal effect on experiment groups by giving some treatments. This research used a quantitative approach due to the research is intended to get the quantitative data, and the data will be analyzed quantitatively. The population of this research is the students of Management Study Program at Universitas Aki who take English Business III.

\section{RESULTS AND DISCUSSION Steps to implement Miss Maya}

Miss Maya is an innovative, creative, imaginative and futuristic integrated learning strategy for English, business and technology in the form of a simple business plan (Sinessa), presentation, assessment and evaluation. In other words, learning English through Miss Maya used simulation techniques (role-playing and discussion).
Simulation technique is very useful for reflecting real life situations and conditions so that students are able to develop their potential optimally to be independent, adaptive to the environment, and capable to survive in the future (Prasasti, 2017). Although Miss Maya could be carried out individually, it would be better when it was done in groups.

The first step is making Sinessa. Sinessa is a summary of all the chapters in the book "First Insight into Business". They are customers, companies, travel, troubleshooting, company history, retailing, products, people, business environment, finance, corporate responsibility, and competition(Robbins, 2006). However, the twelve chapters are grouped into the most six important items in establishing a business, namely: company, people, product, customer and marketplace, finance, and advertisement.

First, company. This item describes the ins and outs of company identity, at least, including the company name, logo, motto, address, telephone and email. Students must name the company and its logo according to the company's vision and mission or briefly describe what field the company is engaged with. The company motto can be taken from the company's vision and mission or the company's performance or even the company's flagship product. Apart from the company name and motto, the rest is complementary and adjusted as long as it is logical.

Second, people. This item explains the structure of the company, the number of workers, divisions, working hours, salaries, and company regulations. A company/ business must have a management structure starting from staff, supervisors, managers, directors to CEO (chief executive officer) and owner. The amount of the division is adjusted to the number of workers and the 
needs of the company. Workers' salaries are also very basic and vital because they involve the needs of many people. There should be a correlation between the number of working hours and salary. The more hours $<<42$ the employees work, the more wages are given. Generally, working hours are 8-9 hours per day including rest hours and the salary can be adjusted to the minimum wage. Apart from wages, company regulations need to be made and obeyed by all employees/ workers in order to create a good and conducive working atmosphere that will affect the company's production and income.

Third, product. Product is the most important icon in a company/ business. Products can be in the form of goods or services. This section should provide explanation about the main product of the company. It can be its USP, competitors, prices and outlets. The USP (unique selling points) makes a company's product different from the same products from other companies (competitors). For example, bath soap. There are Nuvo, Lifebuoy, Lervia, and others that have their own characteristics that distinguish one another. In addition, prices also need special attention because consumers will see and compare prices among existing products. Products that are ready to be marketed also need to be informed where these products can be purchased both wholesale and retail. Usually, wholesale and retail prices also need to be differentiated. The wholesale price is cheaper than the retail price.

Fourth, customer and marketplace. This section includes the types of customers who will be targeted in the market, market share, and the precise markets where the prospective buyers/ customers will easily find the product. In addition, it needs to be an appreciation for loyal customers.
Appreciation can be in the form of vouchers shopping, cash back, door prizes, and so on.

Fifth, finance. This is the most important part of starting a business idea or running a business/ company. Good financial management will affect the company's financial rotation as well. This section includes capital, loan / credit, interest rate, income, tax, outcome, overhead cost, and profit/ loss account. Capital can be defined as an initial fund that can be used to start a business either from individuals or from groups in the form of contributions or investments. If there is a loan from a bank, it is necessary to calculate the monthly installments along with the interest rate. In addition, the correlation between income and tax payments is also a priority for taxcompliant individuals/ companies to maintain the company's reputation in the consumers' mind. Outcome (expenses) must also be done in detail. In addition to employee wages / salaries, overhead costs must be considered, such as electricity costs, telephone, kitchen supply, and others. After that, profit/ loss account will be known.

The sixth is the advertisement. Well, this last part is how to market the products. It is about what media are used and examples of advertisements that have been made, such as attractive brochures/ pamphlets uploaded on the company website or advertising on popular sites like YouTube, Instagram, Facebook, WhatsApp, and so on. Absolutely, in this 4.0 industrial revolution, everything will use automation and internet technology, including the payment system for product delivery.

The next step is presentation. Presentation is an alternative way to significantly reduce student anxiety levels in terms of speaking skills (Aliyu et al., 2019). Apart from the level of anxiety as a nonlinguistic factor, self-confidence and topic 
mastery also affect students' speaking performance. However, with proper treatment and continuous training, these factors can be minimized (Astuti, 2019). Presenting materials according to interests and knowledge is the right way to improve the students' speaking performance.

Miss Maya presentation with a product prototype using English for 15-20 minutes must be in persuasive way. Presentations can be adapted to situations and conditions both online (in the form of video or long-distance communication) or offline (face to face/ in class). The following are the things conveyed in the presentation:

a. Opening and welcoming.

b. Greeting the audience and introduce the group (chief and members).

c. Describing the duties / roles of each member.

d. Presenting Miss Maya project, which is already compiled (starting items 1-6).

e. Showing the product prototype with an explanation of the USP.

f. Answering questions in the QnA session (questions and answers).

g. Delivering business motivation.

h. Closing

The last step is assessment. Assessment is done after students have made a persuasive presentation. In this case, the teacher provides an assessment on how the students made Sinessa and how students deliver their presentation the product prototype to other students as the audience. In addition, teachers can also convey the dos and don'ts in business ethics in entrepreneurship. This assessment is very important to be conveyed in order to create a healthy and dignified business competition.

In the assessment, in addition to the elements of skills speaking such as intonation, fluency, pronunciation, gesture/ expression, creativity, business ideas and future feasibility are also assessed. Therefore, the type of assessment suitable for use in Miss Maya is the performance-based assessment. This assessment takes a long time because it also requires greater effort, integration of language skills, and interactive tasks (Brown, 2004). Among four language skills, speaking can be said to be the most challenging skill for an assessment because it requires a thorough understanding of the criteria being assessed (Joo, 2016). In addition to the assessment model above, an authentic assessment model can also be used where students can apply new information and academic skills in real situations for specific purposes. They must have the competence to display, simulate, or do something that is the essence of wellunderstood knowledge and abilities. This competence must be closely related to what is needed in life such as work place, business, entrepreneurship and others (Rahmawati \& Fatimah, 2015). There are four types of authentic assessments, namely: portfolio, performance measurement, projects, and complete written answers. This authentic assessment of Miss Maya uses performance as an assessment tool as well as making projects and portfolios (Zaim et al., 2020).

\section{The Advantages of Miss Maya in Building Students' Entrepreneurial Leadership}

Although this is a learning strategy and is imaginative futuristic (a dream in the future), Miss Maya is expected to be able to foster the students' entrepreneurial leadership in the future to face and participate in welcoming the industrial revolution4.0. Students are able to take a part in various business fields such as techno-preneurship, creative-preneurship, and others. Through Miss Maya, it is expected that future 
generations will no longer be job seekers but become job creators who employ tens, hundreds or even thousands of workers. Thus, the advantages of Miss Maya can be described as follows: applicative English learning. To be interactive means not monotonous and textual. To be integrative means involving various language skills and entrepreneurial insight. To be applicative means easily to be implemented and related to real life. Strategies and methods that have great potential in English language learning for adult learners in the $21^{\text {st }}$ century are

performance, show, and simulation (Goodwin et al., 2009).

b. It is easy for students to learn the ins and outs of entrepreneurship.

c. It trains public speaking skills of students so that the nervous on the stage does not occur in the future.

d. It trains and fosters solid teamwork to achieve the goals that have been set together.

e. Through Miss Maya, students can develop their positive attitudes that must be possessed as the basic values of entrepreneurship, namely selfconfidence, leadership, interpersonal communication, creativity, originality, and resilience.

\begin{tabular}{|l|c|c|c|c|c|}
\hline & $\mathrm{N}$ & Minimum & Maximum & Mean & Std. Deviation \\
\hline Pronunciation & 17 & 40 & 80 & 62.35 & 15.624 \\
Intonation & 17 & 40 & 80 & 57.65 & 15.624 \\
Fluency & 17 & 40 & 80 & 56.47 & 16.179 \\
Gesture & 17 & 40 & 60 & 47.06 & 9.852 \\
Total Score & 17 & 40 & 75 & 55.88 & 12.149 \\
Valid N (listwise) & 17 & & & & \\
\hline
\end{tabular}

The Effectiveness of Miss Maya in English Learning

These are the results of pretest, posttest, and t-test as the analysis that can be seen from these tables.

Table 1. Descriptive Statistics of Pre-test Score

In pronunciation, intonation, fluency, and gesture has the same minimum score; 40 . For maximum score, pronunciation, intonation, fluency is 80 , and 60 for gesture. The highest score of mean is pronunciation; 62.35, and the lowest is gesture; 47.06. It means that the students are good in pronunciation but not in gesture. They can pronounce the words well, but they are not able to act yet based on the meaning of utterances. The average students' ability in this class is 55.88 . 
Table 2. Post-test Score after treatment

\begin{tabular}{|l|c|c|c|c|c|}
\hline & $\mathrm{N}$ & Minimum & Maximum & Mean & Std. Deviation \\
\hline Pronunciation & 17 & 40 & 80 & 65.88 & 13.720 \\
Intonation & 17 & 60 & 80 & 65.88 & 9.393 \\
Fluency & 17 & 40 & 80 & 58.82 & 14.951 \\
Gesture & 17 & 40 & 100 & 67.06 & 18.630 \\
Total Score & 17 & 50 & 85 & 64.41 & 11.843 \\
Valid N (listwise) & 17 & & & & \\
\hline
\end{tabular}

In fluency, and gesture has the same intonation is 65.88. The minimum of total minimum score; 40. For maximum score, score is 50 and 85 for the maximum one. The pronunciation, intonation, fluency is 80 , and average students' ability in this class is 100 for gesture. The highest score of mean is 64.41 . gesture; 67.06, and the lowest is fluency;

Table 3: Paired Samples Statistics of Pre-test and Post-test

\begin{tabular}{|ll|c|c|c|c|}
\hline & & Mean & N & Std. Deviation & Std. Error Mean \\
\hline Pair 1 & Post-test & 64.4118 & 17 & 11.84303 & 2.87236 \\
& Pre-test & 55.8824 & 17 & 12.14950 & 2.94669 \\
\hline
\end{tabular}

The mean of post-test is 64.41 , and linear and the difference is significant. It the pre-test is 55.88. From the score of means also that all students can increase their standard deviation; post-test < pre-test, 11.84 ability together in speaking linearly. $<12.14$, it means that the learning process is

Table 4: Paired Samples Test of Post-test and Pre-test Score

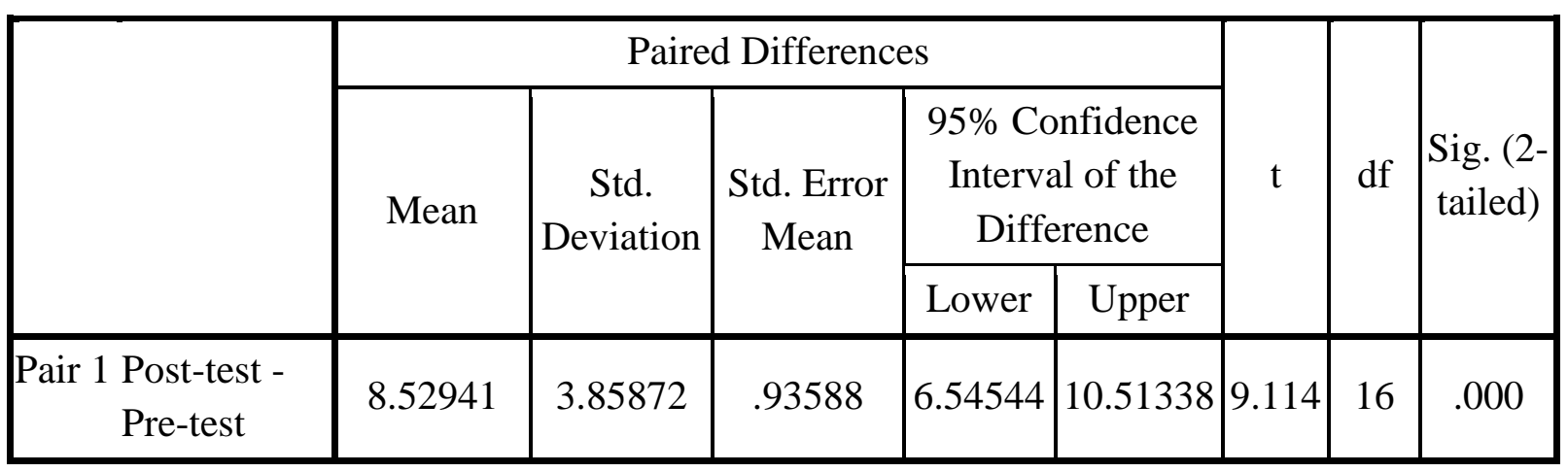


The table above is the main result of analysis. The bases of decision-making are:

- $\mathrm{H}_{0}$ : the average of population before and after are identical.

$\mathrm{H}_{1}$ : the average of population before and after are not identical.

- If the probability $>0.05, \mathrm{H}_{0}$ is accepted, but if the probability $<0.05, \mathrm{H}_{0}$ is rejected.

From the output, we can see that sig. (2tailed) $=0.000$. It means that the probability less than $0.05 ; \mathrm{H}_{0}$ is rejected; the score of pre-test and post-test are not identical. In other words, the use of Miss Maya is effective to be used in English learning.

\section{CONCLUSION}

The conclusion of this research is that the implementation of Miss Mayacan be implemented through the preparation stage (group discussion in making Sinessa), implementation (persuasive presentation accompanied by product prototypes), and assessment. Miss Maya with all its advantages is an integrative English learning strategy that is imaginative and futuristic with six main elements of doing business to foster students' entrepreneurial leadership. They are expected to be able to become a techno-preneurs, creative-preneurs, and other kinds of jobs to face the industrial revolution 4.0.Through t-test analysis which showed that sig. (2-tailed) of all $=0.000$ and the probability less than 0.05 , Miss Maya is an effective strategy to be used in English learning.

\section{REFERENCES}

Aliyu, M. M., Korau, S. M., \& Basiru, A. (2019). Reducing Undergraduates Speaking Anxiety through Class Interactions and Oral Presentations. Asian Journal of Contemporary Education, $\quad 3(1), \quad 36-43$. https://doi.org/10.18488/journal.137.2019.31.36.43

Astuti, E. S. (2019). Faktor-faktor yang Mempengaruhi Speaking Performance Mahasiswa Jurusan Pendidikan Bahasa Inggris. Paradigma: Jurnal Filsafat, Sains, Teknologi, Dan Sosial Budaya, 25(2), 27-33. https://doi.org/10.33503/paradigma.v25i2.543

Brown, H. D. (2004). Language Testing Book: Principles and Classroom Practice. Longman University Press.

Chairiyani, R. P. (2013). Pembelajaran Bahasa Inggris untuk Bisnis melalui E-Learning. Humaniora, 4(2), 1074. https://doi.org/10.21512/humaniora.v4i2.3548

Cole, B. C., \& Smith, D. L. (1993). Cooperative Learning Strategies for Teaching Adult Business English. Journal of Education for Business, 68(3), 170-173. https://doi.org/10.1080/08832323.1993.10117608

Goodwin, K. S., Ostrom, L., \& Scott, K. W. (2009). Journal of Adult Education. Journal of Adult Education, 38(1), 22-42.

Joo, S. H. (2016). Self- and Peer-Assessment of Speaking. Working Papers in TESOL and Applied Linguistics, 16(2), 68-83. http://dx.doi.org/10.7916/D8FN2D1S

Leonardi, V. (2009). Teaching Business English through Translation. Journal of Language and Translation, 10(1), 139-153. https://doi.org/10.22425/jul.2009.10.1.139

Mohamad, N. (2003). Metode Penelitian. Ghalia Indonesia. 
Özdemir, P. (2015). A Combined Approach to Teaching English and Entrepreneurship. Procedia - Social and Behavioral Sciences, 199, 293-297. https://doi.org/10.1016/j.sbspro.2015.07.547

Prasasti, S. (2017). Pengembangan Pembelajaran Kewirausahaan Sejak Dini Melalui Bimbingan Kelompok Teknik Simulasi Game Siklus Bisnis Bagi Siswa. In Prosiding Seminar Nasional Penguatan Peran Guru BK di Sekolah (Issue 1).

Prasetyo, B., \& Trisyanti, U. (2018). Revolusi Industri 4.0 Dan Tantangan Perubahan Sosial. Prosiding SEMATEKOS 3, 5, 22-27. https://doi.org/10.12962/j23546026.y2018i5.4417

Rahmawati, L. E., \& Fatimah, N. (2015). Pengembangan Model Penilaian Autentik Kompetensi Berbicara. Jurnal VARIDIKA, 26(1), 1-10. https://doi.org/10.23917/varidika.v26i1.727

Robbins, S. (2006). First Insights into Business Students' Book. Longman Publisher.

Schwab, K. (2016). The Fourth Industrial Revolution. World Economic Forum.

Sudaryanto. (1986). Metode Lingusitik. Gadjah Mada University Press.

Sugiyarto, E., \& Kusmayadi. (2009). Metodologi Penelitian Dalam Bidang Kepariwisataan (1st ed.). Gramedia Pustaka Utama.

Suprapto, H. A. et al. (2018). Pelatihan Pembuatan Proposal Rencana Bisnis (Business Plan) Bagi Siswa Madrasah Tsanawiyah Nurul Hikmah Dan Smp Al-Ihsan Guna Meningkatkan Kemampuan Berwirausaha. Abdimas Siliwangi, 1(2), 81. https://doi.org/10.22460/as.v1i2p81-88.905

Suwardana, H. (2018). Revolusi Industri 4. 0 Berbasis Revolusi Mental. JATI UNIK : Jurnal $\begin{array}{lllll}\text { Ilmiah Teknik Dan Manajemen } & \text { Industri, }\end{array}$ https://doi.org/10.30737/jatiunik.v1i2.117

Tjandrawinata, R. (2016). Industri 4.0: revolusi industri abad ini dan pengaruhnya pada bidang kesehatan dan bioteknologi. February. https://doi.org/10.5281/zenodo.49404

Zaim, M., Refnaldi, \& Arsyad, S. (2020). Authentic assessment for speaking skills: Problem and solution for english secondary school teachers in Indonesia. International Journal of Instruction, 13(3), 587-604. https://doi.org/10.29333/iji.2020.13340a 
$\longrightarrow$

$<\mid 48$ 